\title{
AZ ISKOLAI AGRESSZIVITÁS MEGNYILVÁNULÁSI FORMÁI, MINT AZ ISKOLAI CSOPORTBAN ELFOGLALT STÁTUSZ MEGHATÁROZÓ TÉNYEZŐI
}

\author{
Szerzők: \\ Demeter Kármen, \\ Babes-Bolyai Tudományegyetem, \\ (Románia) \\ Szabó Kinga \\ Babes-Bolyai Tudományegyetem,
}

(Románia)

Első szerző e-mail címe:

karmen.demeter@ubbcluj.ro

\section{Lektorok:}

Kiss Szidónia

Babes-Bolyai Tudományegyetem,

(Románia)

Bernáth Anna

Babes-Bolyai Tudományegyetem,

(Románia)

Mező Ferenc

Debreceni Egyetem

Kondé Z.-né Inántsy-Pap Judit

Debreceni Egyetem

Demeter, Kármen és Szabó Kinga (2015): Az iskolai agresszivitás megnyilvánulási formái, mint az iskolai csoportban elfoglalt státusz meghatározó tényezői. Különleges Bánásmód, I. évf. 2015/1. szám, 55-66. DOI 10.18458/KB.2015.1.55

\begin{abstract}
Absztrakt
Vizsgálatunkban az egyes agresszivitásformák és a kisiskolások csoportban elfoglalt szociometriai státusza közötti összefüggéseket céloztuk meg, figyelembe véve ezen tényezök hatását az agresszív gyerekek társaikkal szemben megfogalmazott gondolatainak ellenséges voltára. Minta: 321 erdélyi kisiskolást $(M=10,25$ év, SD =0,71) vizsgáltunk, akik közül 61,4\% román és 36,8\% magyar etnikumú diák volt.Módszer: eszközeink segítségével az esetlegesen megjelenö agresszivitás formáját, a gyerekek osztályban elfoglalt szociometriai státuszát, illetve a társakkal szembeni ellenséges gondolatok minöségét mértük. Eredmények: a nemi különbségeknek és szociometriai státusznak hatása van az agresszív viselkedés típusára. Az eredmények a prevenció és intervenció területén alkalmazhatók.
\end{abstract}

Kulcsszavak: reaktív agresszió, proaktív agresszió, szociometriai státusz, ellenséges gondolatok

Diszciplínák: pszichológia, pedagógia

\begin{abstract}
FORMS OF AGGRESSION IN SCHOOLS AS DETERMINING FACTORS IN GAINING SOCIAL STATUS IN A SCHOOL GROUP

In our study we have focused on the relationship between certain types of aggression and the sociometric status of primary school children, considering the effect of these factors on the hostile character of cognitions that aggressive children generate towards their peers. Sample: Our sample consisted of 321 primary school children from Transylvania (M=10.25
\end{abstract}


years, $S D=0.71$ ), out of which $61.4 \%$ were of Romanian and $36.8 \%$ of Hungarian ethnicity. Method: our instruments measured the type of aggression, the sociometric status of children within the classroom and the type of hostile cognitions towards peers. Results: gender differences and sociometric status has effect on types of aggresive behavior. The results are useable in the field for prevention and intervention.

Keywords: reactive aggression, proactive aggression, sociometric status, hostile cognitions

Disciplines: psychology, pedagogy

Tanulmányunk célja megvizsgálni a csoportban elfoglalt státusz szerepét az agresszív gyerekek ellenséges kognícióinak a generálásában, és rávilágítani arra, hogy milyen összefüggés van a csoportban elfoglalt státusz és a viselkedésben megjelenő agresszivitás formái között.

A szakirodalom gyakran foglalkozik a szociometriai státusz és az egyes agresszivitásformák közötti kapcsolat feltárásával, de kevés információnk van arról, hogy milyen interakció van a státusz, agresszivitásforma és a másokkal kapcsolatban megjelenő ellenséges gondolatok között. A társas információfeldolgozás modelljének értelmében, a különböző típusú agresszivitást mutató gyerekek sajátos jellemzőkkel rendelkeznek az információfeldolgozás bizonyos szakaszaiban, és ennek következtében más-más mintázat jellemző társaikkal szembeni viselkedésükre (Crick és Dodge, 1996a; 1996b).

Kutatásunkban a szakirodalomban gyakran említett reaktív, illetve proaktív agresszivitásformákat mérjük fel, és megvizsgáljuk, hogy milyen szociometriai státusz mutatói vannak a mindkét agresszivitásformát mutató gyerekeknek, és milyen összefüggést mutat ez a viselkedés a társakkal szembeni ellenséges gondolatok mértékével.

Tanulmányunk első részében a szociometriai státusz mutatók iskoláskorú gyerekekre vonatkozó szakirodalmát szintetizáljuk, majd a célzott agresszivitás formái és a szociometriai státusz közötti kapcsolatot vizsgáló kutatásokat foglaljuk össze. A tanulmány további részében a vizsgálat módszerét, a vizsgálat lépéseit, illetve eredményeinket mutatjuk be.

\section{Társas státusz, társas preferencia és észlelt népszerüség}

A szakirodalomban az agresszivitás számos formája és funkciója lelhető fel, melyek különbözőképpen asszociálódnak a diákok társas kapcsolataival (Card és tsai., 2008). Az 1980-as évektől kezdődően a szakirodalom több agresszivitástípust jellemez, beleértve ennek közvetlen formáját is, amelyek a társas kapcsolatokon keresztül, illetve a generált érzelmi állapot által sértik az áldozatot (Bjorqvist, Lagerspetz és Osterman, 1992; Crick, 1995; Crick és Grotpeter, 1995). Ezek között a formák között említhető a reaktív agresszió, amely olyan dühre és ellenséges reakcióra vonatkozik, amely provokálásra vagy fenyegetésre adott viselkedés (Steinberg és tsai., 2013). Ennek a formának az ellenpólusánál beszélhetünk a proaktív agresszióról, amely szándékosságot, kezdeményezést és tervezett viselkedést feltételez (Fite, Colder és Pelham, 2006). A szakirodalom alapján elmondható, hogy a reaktív agressziót a kortárscsoportok jobban tolerálják, mint a proaktív agressziót, és az előbbi erős kapcsolatot mutat az általános és középiskolában kialakult csoportbeli preferencia alacsony szintjével (Vitaro, Brendgen és Barker, 2006; Toblin és tsai, 2005).

Az amerikai pszichológusok megközelítése a csoportbeli társas státusz bipoláris (kedveltantipatikus) dimenzióként határozható meg, és mint társas preferencia operacionalizálható (Olweus, 2001). Ez a szemlélet az agresszivitás és az elutasítás közötti kapcsolatra 
összpontosít, egy szoros pozitív kapcsolatot feltételezve a kettő között. Számos tanulmány igazolta, hogy a különböző típusú agresszivitást mutató diákok magas szociális státuszt is mutathatnak (Berger, Batanova és Duncan Cance, 2015; Rodkin és tsai, 2000). Ez abban az esetben jellemző, amikor a státusz nem a kedvelt-antipatikus paraméterek mentén operacionalizált (Farmer és tsai., 2003; Rodkin és mtsai., 2000). Azon adatok, melyek magas szintű népszerüséget és alacsony szintű szimpátiát azonosítottak az agresszív tanulók esetében (Farmer és tsai., 2003), fogalmi megkülönböztetést használtak a szociometriai népszerüség és az észlelt népszerüség között. A szociometriai népszerüség az osztályban mutatkozó társas népszerüségi szint alapján határozható meg (a diák kedvelt a társai által vagy antipatikus nekik) (Rubin, Bukowski és Parker, 1998). Az észlelt népszerüséget azáltal határozták meg, hogy felmérték azt a népszerüséget, amit egy diák társának tulajdonít, annak (Adler és Adler, 1998). Az adatok alapján elmondható, hogy az agresszivitás negatív kapcsolatban áll a tulajdonképpeni népszerüséggel, ugyanakkor pozitívan kapcsolódik a diák észlelt népszerüségéhez (Cillessen és Mayeux, 2004). A longitudinális vizsgálatok arra a következtetésre jutottak, hogy ez a kapcsolat nagyon erős a gimnáziumi osztályoktól kezdődően egészen a serdülőkorig (Cillessen és Mayeux, 2004; Rose, Swenson és Waller, 2004). Azon kutatások eredményei, melyek az agresszív diákok társas kapcsolatait vizsgálták, ambivalens összefüggést állapítottak meg e két faktor között (Farmer és tsai., 2003). Azok az agresszív diákok, akik társaik által ki vannak rekesztve, más csoportok tagjaivá válhatnak, és ott befolyásos szerepeket tölthetnek be (Bagwell és tsai., 2000). A népszerüség és a szociometriai státusz közötti kapcsolat ellentmondásos: több népszerü diák vezetőként jelenik meg egy csoportban, ugyanakkor társas szempontból társaik nem kedvelt diákokként tartják őket számon (szociometrás státusz) (Lease, Kennedy és Axelrod, 2002).

\section{Az iskolai agresszivitás}

\section{formáinak és funkcióinak összefüggése a diákok társas kapcsolataival}

Az iskolai társas kapcsolatokat a leggyakrabban a következő agresszivitásformákkal vizsgálták: közvetett-közvetlen agresszivitás, nyílt-rejtett agresszivitás, instrumentális agresszivitás, illetve kapcsolati agresszivitás. Az agresszivitás funkciói közül tanulmányunk a proaktív és a reaktív funkciók vizsgálatára összpontosít. Az iskolai környezetben megjelenő agresszor, illetve az áldozat viselkedésének meghatározásában az említett funkcióknak nagy jelentősége van (Crick és Dodge, 1994; Dodge és Coie, 1987).

A reaktív agresszivitás haragot és ellenséges viselkedést feltételez, mely egy kihívásra adott reakcióként nyilvánul meg. Ezzel ellentétben a proaktív agresszivitás célorientált, megtervezett, és megjelenése nem feltételez haragot vagy más provokatív ingert. Egy, a közelmúltban (Card és Little, 2006) megjelent metaanalízis eredményei arra engednek következtetni, hogy mind a proaktív, mind pedig a reaktív agresszív viselkedés gyenge szociometriai státusszal áll kapcsolatban. A reaktív agresszivitás és a gyenge társas státusz között a kapcsolat erősebb, mint a proaktív agresszivitás és a negatív státuszok között. Általában a reaktív agresszivitás kevésbé tolerált a társak által, mint proaktív, és alacsony szintü társas népszerüséget eredményez (Vitaro és tsai., 2006). Az agresszivitás és a népszerütlenség kapcsolata viszont nem egyértelmü. A szakirodalomban néhány esetben a népszerü gyerekek mutatnak magasabb reaktivitás szintet, és esetenként az agresszivitás egyáltalán nem észlelhető (Cillessen és Mayeux, 2004).

A társas státusz egyik mutatója lehet a csoportból való kizárás, a kirekesztés is (Killen, Mulvey és Hitti, 2013). Az akkut kirekesztés ellenséges attribúciókat eredményez a gyerek kognícióiban, és ez számos esetben agresszív megnyilvánulásokhoz vezet (Peets, Hodges és Salmivalli, 2011). 


\section{Módszer}

Tanulmányunknak két fó célja van. Elsősorban azt szerettük volna feltárni, hogy milyen kapcsolat áll fenn erdélyi kisiskolások körében a különböző típusú agresszivitás (proaktív és reaktív) és az osztályban megmutatkozó szociális státusz között. Továbbá értékelés alá kerülnek a gyerekek társaikkal szemben megfogalmazott spontán kogníciói, a csoportban elfoglalt szociometriai státusz, illetve az agresszív gyerekek viselkedésmutatói közötti összefüggések. A szakirodalomra és az elméleti alapokra támaszkodva három hipotézist fogalmaztunk meg:

1. Hipotézis: A reaktív agresszív gyerekek több ellenséges gondolatot fogalmaznak meg az általuk nem kedvelt társakkal kapcsolatosan, szemben a proaktív agresszív gyerekekkel.

2. Hipotézis: A reaktív-proaktív agresszív gyerekek a legkevésbé kedvelt alcsoportját képezik az iskolai osztálynak.

3. Hipotézis: Gyenge szociometriai státusz esetében a gyerekek kevésbé negatív gondolatokat fogalmaznak meg kedvelt társaikkal szemben, és negatívabbakat nem kedvelt társaikkal szemben.

A célok elérése érdekében egy korrelációs design-ú kutatást valósítottunk meg egy 342 diákból álló mintán, akik különböző erdélyi iskolák 16 osztályából származtak.

\section{Minta}

Az adatokat 342 IV.-V. osztályos diáktól gyüjtöttük be. A gyerekek három erdélyi megyéből származtak. A minta a nemek szerinti eloszlást tekintve szinte egyenlö, résztvevőink között 46,4\% fiú és 54,6\% lány volt. A nemzetiség tekintetében az eloszlás a következőképpen alakult: 61,4\% román és 36,8\% magyar etnikumú diák. Az életkort tekintve, az átlag $M=10,25$ év $(S D=0,71)$. Statisztikai feldolgozásra alkalmas teljes adatsort összesen 321 diákól kaptunk, ők képezték végső mintánkat. A minta etnikai szempontból reprezentatív volt az Erdélyre jellemző megoszlásra.

\section{Eszközök}

1. Az osztálytársakkal szembeni Attitüd Kérdőív (AC) (magyar nyelvü adaptált változat Demeter, 2011 által, az olasz kérdőív alapján, Camodeca, 2010). A kérdőív 30 kijelentést tartalmaz arra vonatkozóan, hogy milyen a diák viselkedése társaival szemben. A kérdőív adaptált változata a Reaktív, Proaktív, Fizikai-nyílt, illetve Kapcsolati agresszivitás alskálákat tartalmazta. A kérdőív alapján a résztvevő diákokat négy kategóriába soroltuk: nem agresszív gyerekek, reaktív diákok, proaktív diákok, reaktív-proaktív diákok (a reaktív és proaktív alskálán is átlagon felüli pontértéket elért diákok).

2. Szociometriai Státusz - Hat kérdésböl álló adatlap, mely a diákok csoportban elfoglalt társas helyzetének a megállapítására, illetve a vizsgált csoport társas mátrixának a feltérképezésére alkalmas (Cillessen és Mayeux, 2004; Newcomb, Bukowski és Pattee, 1993). A társak között elfoglalt pozíció alapján hat státuszmutatót számoltunk: kedvelt, nem kedvelt, népszerü, nem népszerü, barát, társak által csodált.

3. Prompt (Caravita és Demeter, 2010) - Az előfeszítés technikáját alkalmazó eszköz, amely az osztályon belüli társas kapcsolatok típusa és az osztálytársakkal szembeni attribúciók agresszív minősége közötti összefüggést méri fel. Az eszköz hat instrukciócsomagot tartalmaz, amely alapján a vizsgálati személy tulajdonságokat társít olyan osztálytársakhoz, akikkel különböző társas kapcsolatban van: kedvelt társ, nem kedvelt társ, legjobb barát, csodált társ, népszerü társ, népszerütlen társ. A válaszadás gyorsan történik. A válaszadó diák maximum három asszociációt fogalmazhat meg társaival kapcsolatban. Az eszköz az előfeszítést használja annak érdekében, hogy 
megállapítsa a társas kapcsolatok hatását az agresszív, illetve a nem agresszív gondolatok kialakulására, aktuális provokálás hiányában (Caravita és Demeter, 2010).

\section{Eljárás}

A diákoknál jelentkező agresszivitás típusának és mértékének megállapítása érdekében az osztályban minden tanulót felmértünk az AC kérdőív adaptált változatával. A diák osztályközösségben elfoglalt társas helyzetének meghatározása céljából hat értéket számítottunk, melyek az alábbi szociometriai státuszok indexeként szolgáltak:

- A társas népszerüség mértéke (kedvelt-antipatikus)

- A barátságosság mértéke (barát)

- Az észlelt népszerüség szintje (népszerü-nem népszerü)

- A csodálat szintje (csodált társ)

Az osztálytársakkal kapcsolatos attribúciók jellemzőinek meghatározása céljából a Prompt eszközt használtuk fel (Caravita és Demeter, 2010). A válaszok kódolását 4 értékelö (pedagógus) végezte. Az értékelők közötti megegyezés megfelelő volt, Cronbach á =0,97. A végső érték kiszámítása érdekében azokat a pontszámokat vettük figyelembe, amelyek esetében az értékelők közül legalább 3 egyetértett.

A statisztikai adatfeldolgozás során az SPSS program 20. változatát használtuk.

\section{Eredmények}

Mivel a szakirodalom gyakran említ nemi különbségeket az agresszivitás mutatóiban, független mintás $t$-próbával vizsgáltuk az esetleges eltéréseket.

A leíró statisztikai elemzés eredményeként megállapítható, hogy az agresszív viselkedés funkcióban a nemek között különbség észlelhető. A fiúk csoportja szignifikánsan több reaktív és proaktív agresszív viselkedést mutat az osztályban (lásd: 1. táblázat). Továbbá látható, hogy a hatáskülönbség nagyobb a reaktív agresszivitástípus esetében $(d=0,66)$, mint a proaktívnál $(d=0,33)$.

1. táblázat: Nemi különbségek az iskolás gyerekek típusában (forrás: Demeter és Szabó, 2015)

\begin{tabular}{|l|c|c|c|c|c|c|}
\hline Agresszivitás típusa & Nem & M & SD & t (319) & p & Cohen's d \\
\hline Reaktív & Fiúk & 1,73 & 0,60 & \multirow{2}{*}{5,95} & 0,001 & 0,66 \\
\cline { 2 - 5 } & Lányok & 1,40 & 0,39 & & & \\
\hline Proaktív & Fiúk & 1,29 & 0,42 & \multirow{2}{*}{2,86} & 0,004 & 0,33 \\
\cline { 2 - 4 } & Lányok & 1,17 & 0,30 & & & \\
\hline
\end{tabular}

Hasonlóképpen eltérést találtunk a fiúk és lányok csoportja között a reaktív-proaktív agresszivitás megjelenési gyakorisága esetében. A fiúk nagyobb arányban mutatják az agresszivitás ezen összetett formáját (lásd: 2. táblázat). Ez a különbség közepes erősségü ( $d=$ $0,55)$. 
2. táblázat: Nemi különbségek a reaktív-proaktív agresszivitás szintjében az iskoláskorú gyerekeknél (forrás: Demeter és Szabó, 2015)

\begin{tabular}{|c|c|c|c|c|c|c|}
\hline Agresszivitás típusa & Nem & M & SD & t (84) & p & Cohen's d \\
\hline \multirow{2}{*}{ Reaktív-Proaktív } & Fiúk & 3,98 & 0,91 & \multirow{2}{*}{2,13} & \multirow{2}{*}{0,036} & \multirow{2}{*}{0,55} \\
\hline & Lányok & 358 & 070 & & & \\
\hline
\end{tabular}

E különbségekből kiindulva megvizsgáltuk az ellenséges kogníciók (attribúciók) típusát és gyakoriságát mind a lányok, mind pedig a fiúk esetében. A százalékos megoszlás alapján látható, hogy a fiúk a legtöbb ellenséges kogníciót a népszerütlen és nem kedvelt társaikkal szemben fogalmazták meg. Ez a mintázat minden típusú agresszivitás esetében jelen volt, de megjelent a nem agresszív fiúk csoportjában is (lásd: 1. ábra).

1. ábra: Az ellenséges kogníciók megoszlása különböző agresszív viselkedések függvényében, a fiúk mintájában (forrás: Demeter és Szabó, 2015)

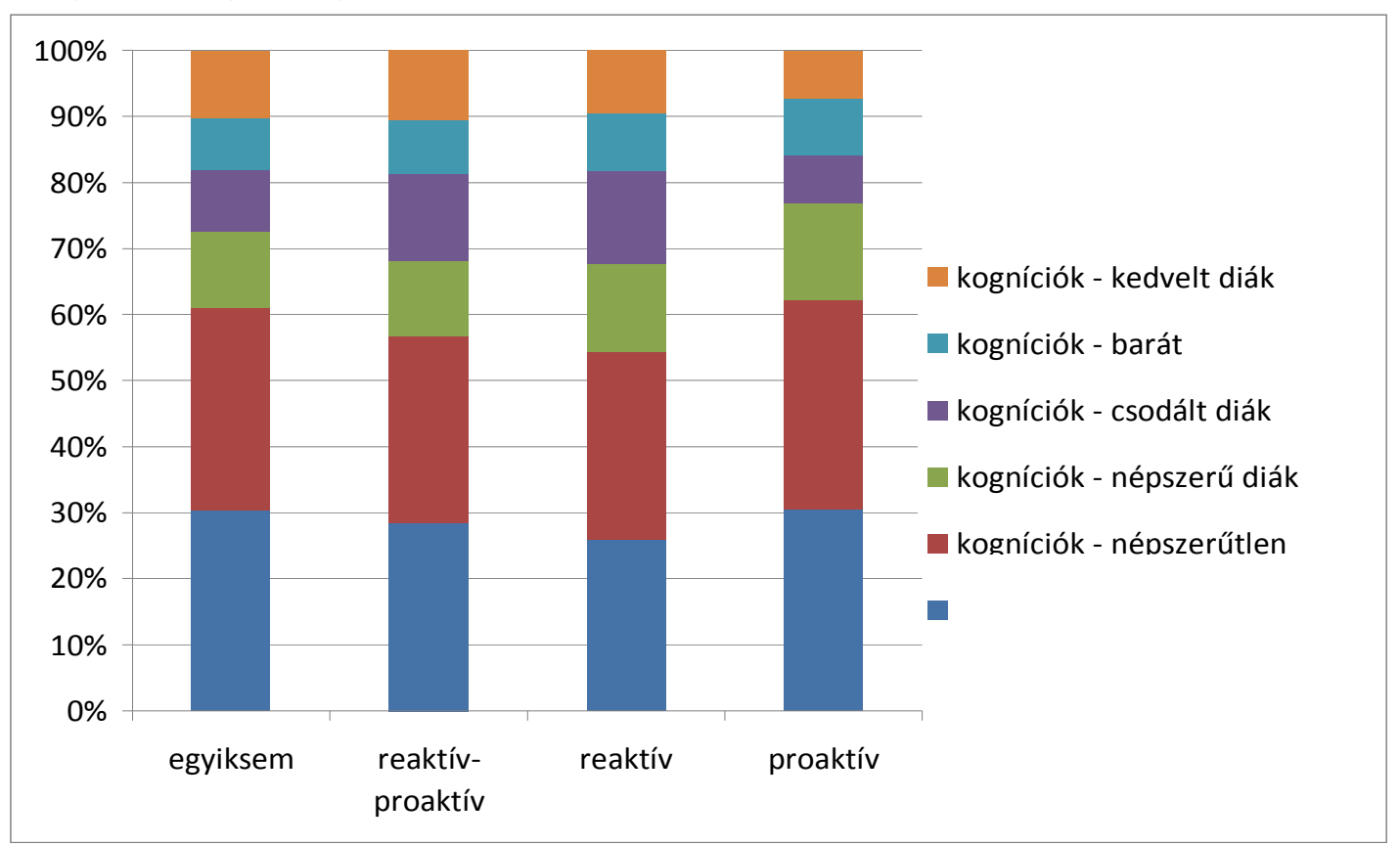

Ez arra utalhat, hogy a népszerütlen és a nem kedvelt gyerekek a legveszélyeztetettebbek az ellenséges attitüdök szempontjából. Tehát velük szemben társaik, az agresszivitás jelenlététől függetlenül, gyakrabban fogalmaznak meg ellenséges és negatív gondolatokat.

A százalékos megoszlást vizsgálva látható, hogy a lányok csoportjában is a legtöbb ellenséges kogníció a népszerütlen és a nem kedvelt diákokkal szemben született. Ez a mintázat minden típusú agresszivitás esetében jelen volt, és megjelent a nem agresszív lányok csoportjában is (lásd: 2. ábra). Érdekes módon, a reaktív-proaktív lányok a népszerütlen osztálytársakkal szemben voltak a legellenségesebbek. A három agresszív csoport közül a reaktív lányok fogalmazták meg a legtöbb negatív kogníciót a kedvelt társaikkal szemben. 
2. ábra: Az ellenséges kogníciók megoszlása különbözö agresszív viselkedések függvényében, a lányok mintájában (forrás: Demeter és Szabó, 2015)

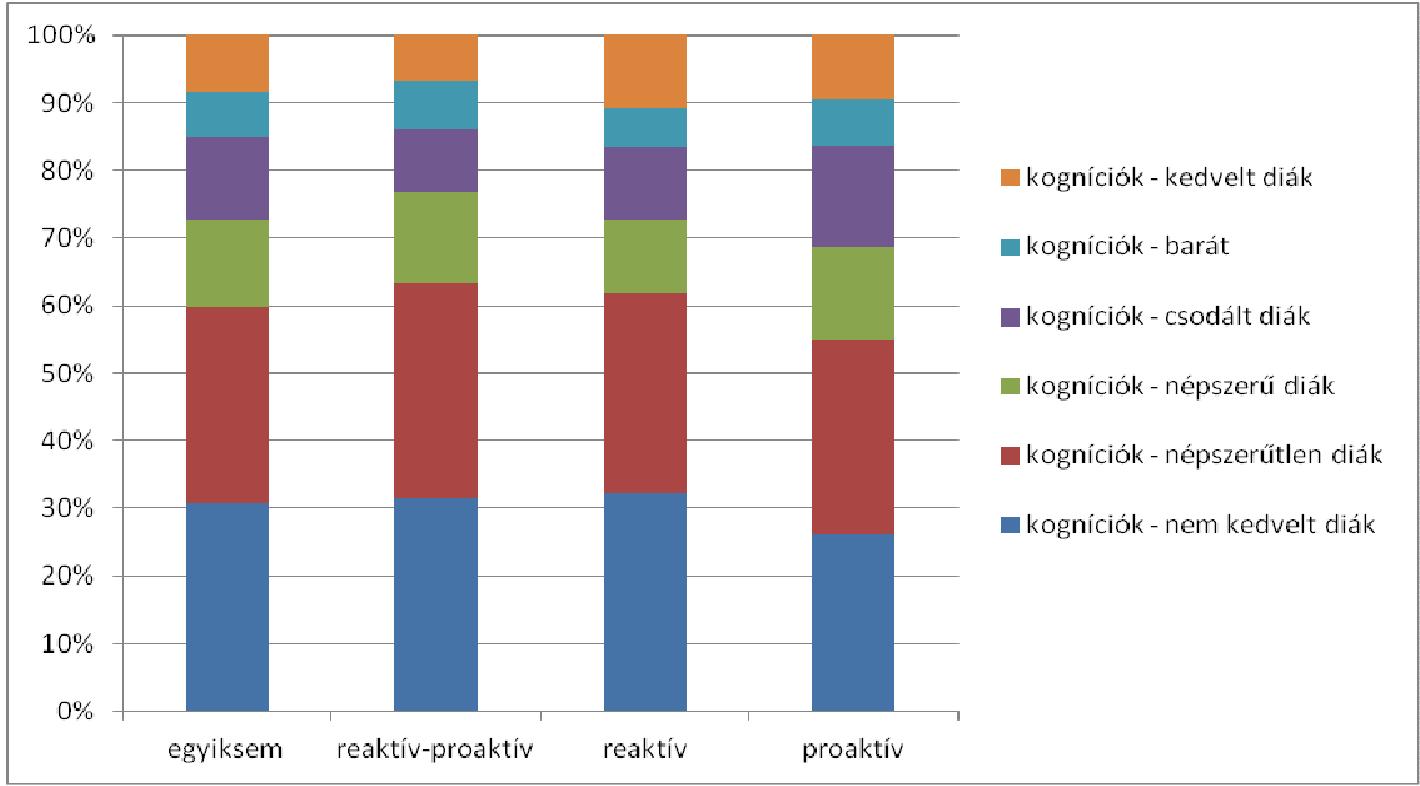

\section{Hipotézisek vizsgálata}

Első hipotézisünk alapján azt feltételeztük, hogy a reaktív agresszív gyerekek több ellenséges gondolatot fogalmaznak meg az általuk nem kedvelt társakkal kapcsolatosan, szemben a proaktív agresszív gyerekekkel. A két független minta összehasonlításához $t$ próbát alkalmaztunk. Nem találtunk szignifikáns különbséget a reaktív $(M=1,94 ; S D=0,72)$ és a proaktív $(M=1,81 ; S D=0,95)$ gyerekek csoportja között nem kedvelt társaikkal szemben megfogalmazott ellenséges kogníciók szempontjából $(t(55)=0,55 ; p=0,57)$.

Következő lépésként megvizsgáltuk a különbségeket nemek szerint is. Tendenciát figyeltünk meg reaktív-proaktív $(M=2,17 ; S D=0,79)$ lányok esetében arra, hogy ellenségesebben vélekedjenek nem népszerü társaikról, mint a proaktív lányok $(M=1,75 ; S D$ $=0,45)(t(44)=1,74 ; p=0,08)$.

Második hipotézisünk esetében azt feltételeztük, hogy a reaktív-proaktív gyerekeket a társaik kevésbe kedvelik. Első lépésként megvizsgáltuk a különböző csoportbeli státuszok százalékos eloszlását az agresszivitás formáinak függvényében (lásd: 3. ábra).

Kimutatásunk azt jelezte, hogy a reaktív-proaktív gyerekek a legkevésbé kedveltek az osztályban, ezt követik a reaktív, proaktív, illetve a nem agresszív gyerekek. Független mintás t-próbával ellenőriztük, hogy szignifikáns-e az eltérés a vizsgált csoportok között. Az eredményeink alapján elmondható, hogy a legtöbb státuszmutató esetében jelentős eltérés van a reaktív-proaktív és a nem agresszív gyerekek között (lásd: 3. táblázat). A hatás erőssége szempontjából a nem kedveltség szintjén tér el leginkább a reaktív-proaktív és a nem agresszív gyerekek csoportja.

Harmadik hipotézisünkkel arra voltunk kíváncsiak, hogy hogyan befolyásolják a gyerekek gyenge szociometriai státuszai társaikkal szembeni kognícióikat. Feltételezéseink alapján a gyenge szociometriai státusz esetében a gyerekek kevésbé negatív gondolatokat fogalmaznak meg kedvelt társaikkal szemben, és negatívabbakat nem kedvelt társaikkal szemben. Ennek az összefüggésnek a feltárása érdekében korrelációs számításokat végeztünk. Az eredményeink azt mutatják, hogy a népszerütlen és nem kedvelt gyerekek kedvelt osztálytársaikkal szemben kevésbé ellenséges kogníciókat fogalmaznak meg $(r=-0,13 ; p<0,05 ; r=-0,12 ; p<0,05)$. A 
társaik által csodált gyerekek kevésbé agresszív gondolatokat táplálnak népszerütlen társaikkal szemben $(r=-0,11 ; p<0,05)$. Fontos megjegyezni viszont, hogy ezek a mutatók csak fiúk esetében jelentkeztek ( $r=-0,20 ; p<0,05 ; r=-0,17 ; p<0,05 ; r=-0,22 ; p<0,01)$, a lányok csoportjában nem mutatkozott jelentős kapcsolat a saját csoportbeli státusz és a másokkal szemben megfogalmazott gondolatok agresszív jellege között.

3. ábra: Az osztályban elfoglalt státusz eloszlás az agresszivitás formái függvényében (forrás: Demeter és Szabó, 2015)

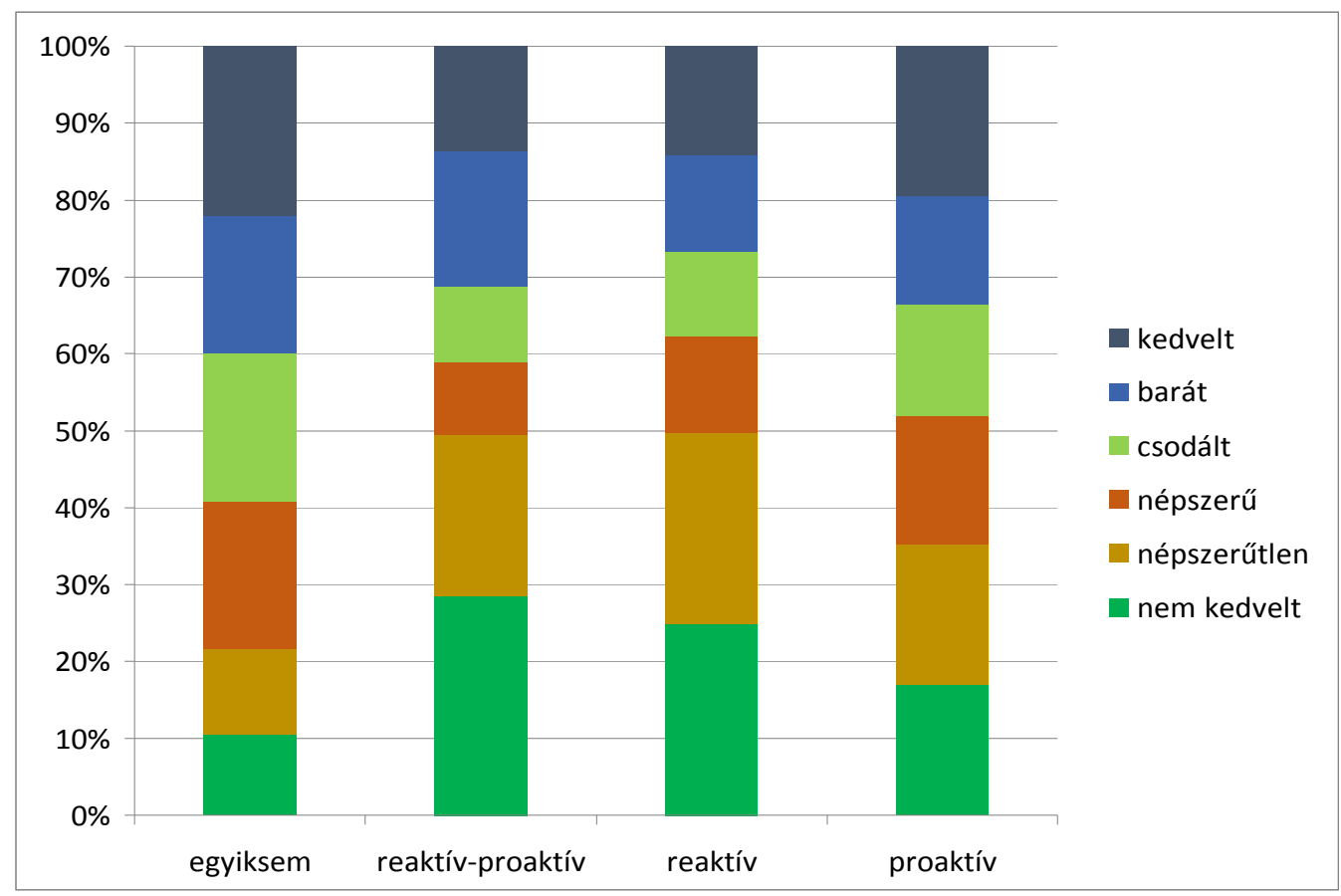

3. táblázat: A nem agresszív és reaktív-proaktíiv csoportok közötti eltérések a szociometriai státusz függvényében (forrás: Demeter és Szabó, 2015)

\begin{tabular}{|c|c|c|c|c|c|c|}
\hline Szociometriai státusz & Csoportok & $\mathbf{M}$ & SD & $t(260)$ & $\mathbf{p}$ & Cohen's d \\
\hline \multirow{2}{*}{ Nem kedvelt } & nem agresszív & 0,80 & 1,53 & \multirow{2}{*}{$-4,70$} & \multirow{2}{*}{0,001} & \multirow{2}{*}{$-0,61$} \\
\hline & reaktív-proaktív & 2,05 & 2,78 & & & \\
\hline \multirow{2}{*}{ Kedvelt } & nem agresszív & 1,67 & 1,73 & \multirow{2}{*}{3,42} & \multirow{2}{*}{0,001} & \multirow{2}{*}{0,45} \\
\hline & reaktív-proaktív & 0,98 & 0,96 & & & \\
\hline \multirow{2}{*}{ Barát } & nem agresszív & 1,35 & 1,29 & \multirow{2}{*}{0,45} & \multirow{2}{*}{0,651} & \multirow{2}{*}{0,06} \\
\hline & reaktív-proaktív & 1,27 & 1,09 & & & \\
\hline \multirow{2}{*}{ Népszerü } & nem agresszív & 1,45 & 2,51 & \multirow{2}{*}{2,50} & \multirow{2}{*}{$\mathbf{0 , 0 1 3}$} & \multirow{2}{*}{0,33} \\
\hline & reaktív-proaktív & 0,69 & 1,75 & & & \\
\hline \multirow{2}{*}{ Csodált } & nem agresszív & 1,46 & 1,94 & \multirow{2}{*}{3,37} & \multirow{2}{*}{$\mathbf{0 , 0 0 1}$} & \multirow{2}{*}{0,45} \\
\hline & reaktív-proaktív & 0,70 & 0,98 & & & \\
\hline \multirow{2}{*}{ Népszerütlen } & nem agresszív & 0,84 & 1,92 & \multirow{2}{*}{$-2,25$} & \multirow{2}{*}{0,025} & \multirow{2}{*}{$-0,29$} \\
\hline & reaktív-proaktív & 1,51 & 2,82 & & & \\
\hline
\end{tabular}




\section{Megvitatás}

Adatfeldolgozásunk során elsősorban arra fókuszáltunk, hogy megvizsgáljuk a nemek között jelentkező eltéréseket az agresszivitás mentén. A szakirodalom alátámasztja, hogy a lányokhoz viszonyítva a fiúk nagyobb arányban folyamodnak proaktív, illetve reaktívproaktív típusú agresszivitásmintázatokhoz (Camodeca és tsai., 2002).

Gyengébb szociális státusszal rendelkező diákok esetében eredményeink részben kongruensek a szakirodalom eredményeivel a velük szemben megfogalmazott ellenséges kogníciók szempontjából. A társas információfeldolgozás elmélet értelmében a reaktív agresszív gyerekek több ellenséges gondolatot fogalmaznak meg a többi diákkal szemben (Crick és Dodge, 1996a, 1996b). Mintánkban ez a tendencia viszont nem agresszív gyerekek esetében is előfordult. Ez a népszerütlen és a nem kedvelt diákok sérülékenységére utal. A fiúkhoz viszonyítva a lányok esetében a reaktív-proaktív és a reaktív alcsoportban mutatkoztak eltérések. A reaktív-proaktív lányok népszerütlen társaikkal szemben a legellenségesebbek, míg a reaktív lányok nem kedvelt társaikkal szemben fogalmazzák meg a legtöbb negatív attribúciót. Ez alátámasztja a szakirodalomban említett jelenséget, mely szerint a reaktív és a proaktív agresszív gyerekek esetében gyakoriak az érzelmi zavarok, az antiszociális megnyilvánulások (Fite és tsai., 2009).

Első hipotézisünkre vonatkozó eredményeink alapján arra következtethetünk, hogy nem differenciálhatunk mintánkban a különböző agresszivitásformát mutató gyerekek között annak alapján, hogy milyen mértékben ellenségesek attribúcióik nem kedvelt társaikkal szemben. Ez az eredmény több feltevés megfogalmazását is lehetővé teszi:

1. Az ellenséges kogníciók elsősorban valós, aktív helyzetekben, provokálás vagy fenyegetés esetén aktiválódnak, ezért a nem kedvelt társak felidézése nem megfelelö módszer az ilyen különbségek beazonosítására.

2. A reaktív és proaktív gyerekek esetében az ellenséges kogníciók aktiválása hasonló mechanizmust követ, a társas információfeldolgozás (Crick és Dodge, 1996a; 1996b) folyamata ezen a ponton nem tér el a két forma esetében.

3. A nemek esetében eltérő mintázat alapján alakulnak ki az ellenséges válaszok, ezért a nem szempontjából heterogén mintán a specifikus mintázatok nem kimutathatók.

Ezt az utóbbi feltevést az is alátámasztja, hogy lányok esetében eltérést találtunk a reaktívproaktív és a proaktív lányok ellenséges gondolatait illetően. Ezek a kogníciók a népszerütlen gyerekek ellen irányultak, és a reaktív-proaktív lányoknál mutattak magasabb szintet.

Bár a szakirodalomban a nem és agresszivitás formái függvényében hasonló adatról nem tudunk, mintánk alapján arra következtethetünk, hogy a reaktív-proaktív lányok esetében a társak gyengébb szociometriai státusza gyakrabban társul ellenséges, agresszív gondolatokkal, mint a szándékos, tervezett agresszivitást mutató lányoknál.

Második hipotézisünk kapcsán megfogalmazhatjuk azt a következtetést, hogy az osztályközösségen belül a reaktív-proaktív agresszivitást mutató gyerekek szociometriai státusza a leggyengébb, és általában ők a legkevésbé kedvelt és népszerü gyerekek. Ez a tulajdonság viszont nem elég jelentős ahhoz, hogy ennek alapján azt mondhatnánk, a gyenge státuszmutatók sajátosan erre a csoportra jellemző vonást képeznek. A társas kapcsolatok ezen mutatója csupán a nem agresszív gyerekekhez viszonyítva mutat statisztikailag jelentős eltérést. Ez az eredmény részben támasztható alá a legfrissebb szakirodalomban fellelhető kutatási eredményekkel, mivel számos esetben a proaktív csoporthoz viszonyítva a reaktív és a reaktív-proaktív gyerekek szignifikánsan gyengébb szociometriai státuszt mutatnak (Stoltz és tsai., 2015). 
Harmadik hipotézisünk eredményei azt sugallják, hogy az osztályban betöltött szociometriai státusz pozitív vagy negatív jellegétől függően eltérés van a gyerekek társaikkal szemben megfogalmazott kognícióik ellenségességében. Úgy tünik, hogy egyes negatív szociometriai státuszok (népszerütlen, nem kedvelt) a tőlük távol álló, pozitív státuszú gyerekekkel szemben kevésbé ellenségesek, míg bizonyos pozitív szociometriai pozíciók (pl. csodált gyerek) inkább a negatív státuszú osztálytársakkal szemben elfogadóbbak (népszerütlen társ).

\section{Korlátok}

Módszertani szempontból korlátot képez vizsgálatunkban az agresszív gondolatok előfeszítés révén történő felmérése, mivel valós helyzetben, esetleges provokáló, ellenséges vagy ambivalens viselkedés esetében a generált asszociációk feltételezhetően valósabbak, esetleg intenzívebbek, mint az általunk használt eljárás során megjelent válaszok. Ugyanakkor, a felmérést nagymértékben befolyásolhatta a gyerek pillanatnyi hangulata. Ennek kiküszöbölésére alkalmas lehetett volna egy hangulatot mérö eszköz alkalmazása, esetleg többszöri felmérés alkalmazása.

A másik korlát az egyes agresszív alcsoportokba kerülő alacsony elemszámból származhat. Bár összességében nagy mintán dolgoztunk, a nem, etnikum, agresszivitás formájának függvényében kialakult alcsoportjaink alacsony létszámmal rendelkeztek.

Vizsgálatunk egy nagyobb terjedelmü kutatás része, jelen tanulmányunkban pedig nem elemeztünk olyan fontosnak tekinthető változók hatását, mint például a résztvevők etnikai hovatartozása. Ez torzíthatja az eredmények általánosíthatóságát, mivel a kisebbségi vagy többségi csoportba való tartozás csoportdinamika szempontjából fontos befolyásoló tényezőt képezhet.

\section{Konklúziók}

Vizsgálatunkban azt tüztük ki célul, hogy az egyes agresszivitásformák és a kisiskolások csoportban elfoglalt szociometriai státusza közötti összefüggéseket azonosítsuk, figyelembe véve ezen tényezők hatását az agresszív gyerekek társaikkal szemben megfogalmazott gondolatainak ellenséges, agresszív voltára.

Elsődleges adataink alapján kimutattuk, hogy a kisiskolás fiúk nagyobb arányban folyamodnak reaktív, proaktív, illetve reaktív-proaktív típusú agresszív viselkedéshez, mint a lányok.

Mintánkban igazolást nyert, hogy a népszerütlen és nem kedvelt diákokkal szemben általában több negatív kogníció születik. Velük szemben viszont a nem agresszív gyerekek is ellenségesebbek.

Nemi különbségeket is találtunk az ellenséges gondolatok generálásában, a fiúk csoportjával ellentétben ugyanis a reaktív-proaktív lányok népszerütlen társaikkal szemben a legellenségesebbek, míg a reaktív lányok nem kedvelt osztálytársaikkal szemben.

Eredményeink arra utalnak, hogy a nem kedvelt társakkal kapcsolatos ellenséges gondolatok általánosak az agresszív gyerekek körében, nincs jelentős különbség az egyes agresszivitásformákat mutató gyerekek csoportjai között.

Azt is sikerült igazolni, hogy a reaktív-proaktív agresszivitást mutató gyerekek szociometriai mutatói a leggyengébbek, általában ők a legkevésbé kedvelt és népszerü gyerekek. A reaktív-proaktív gyerekek negatív csoportstátusza viszont csak a nem agresszív gyerekekkel szemben mutat jelentős eltérést, a többi agresszív csoporthoz viszonyítva ez a különbség nem szignifikáns. Vizsgálatunk harmadik fókuszpontját a szociometriai státusz és a generált ellenséges gondolatok összefüggése képezte. Eredményeink azt mutatják, hogy a népszerütlen, nem kedvelt gyerekek a pozitív státuszú gyerekekkel szemben elfogadóbbak 
(kevésbé ellenséges gondolatok). Bizonyos pozitív szociometriai pozíciók (pl. csodált gyerek) a negatív státuszú (népszerütlen társ) osztálytársakkal szembeni elfogadást valószínüsítik.

Eredményeinket leginkább a prevenció és intervenció területén szeretnénk a gyakorlatban alkalmazni, az agresszivitás kognitív és társas korrelátumainak ismeretében pedagógusoknak, nevelőknek, pszichológusoknak tudunk hatékony, csoportszintü prevenciós intervencióprogramokat ajánlani.

\section{Irodalom}

Adler, P.A., \&Adler, P. (1998). Peer power: Preadolescent culture and identity. New Brunswick, NJ: Rutgers University Press

Bagwell, C.L., Coie, J.D., Terry, R.A. \& Lochman, J.E. (2000). Peer clique participation and social status in preadolescence. Merrill-Palmer Quarterly, 46, 280-305.

Berger, C., Batanova, M., \& Duncan Cance, J. (2O15). Aggressive and Prosocial? Examining latent profiles of behavior, social status, Machiavellianism, and Empathy. Journal of Youth and Adolescence, 1-15.

Bjorkqvist, K., Lagerspetz, K., \& Osterman, K. (1992). Direct and Indirect Aggression Scales (DIAS). In K. Bjorkqvist și K. Osterman (1998). Pro Facultate (4) Scales for Research on Interpersonal Relations. Abo-Finland: Abo-Akademi University

Camodeca, M., Goossens, F.A., Terwogt, M.M. \& Schuengel, C. (2002). Bullying and Victimizationa Among School-age Children: Stability and Links to Proactive and Reactive Aggression. Social Development, 3, 332-345.

Card, N.A., \& Little, T.D. (2006). Proactive and reactive aggression in childhood and adolescence: A meta-analysis of differential relations with psychosocial adjustment. International Journal of Behavioral Development, 30, 466-480.

Card, N.A., Stucky, B.D., Sawalani, G.M. \& Little, T.D. (2008). Direct and Indirect Aggression During Childhood and Adolescence: A Meta-Analytic Review of Gender Differences, Intercorrelations, and Relations to Maladjustment. Child Development, 79, 5, 1185-1229.

Caravita, S., Demeter, K. (2010). Executive functioning, cognitive outcomes and specific peer relationships as differentiating factors for reactive and proactive aggressive behavior in primary school. Unpublished research report, University of Brescia

Cillessen, A.H., \& Mayeux, L. (2004). From censure to reinforcement: Developmental changes in the association between aggression and social status. Child Development, 75, 147-163.

Crick, N. R. (1995). Relational aggression: The role of intent attributions, feelings of distress, and provocation type. Development and Psychopathology, 7, 313-322.

Crick, N. R., \& Grotpeter, J. K. (1995). Relational aggression, gender, and socialpsychological adjustment. Child Development, 66, 710-722.

Crick, N., \& Dodge, K. (1996a). Social information-processing mechanisms in reactive and proactive aggression. Child Development, 67, 993-1002.

Crick, N.R., \& Dodge, K.A. (1996b). Social information-processing mechanisms on reactive and proactive aggression. Personality and Social Psychology Bulletin, 67, 3, 993-1002.

Crick, N. R., \& Dodge, K. A. (1994). A review and reformulation of social information processing mechanisms in children's social adjustment. Psychological Bulletin, 115, 74- 101.

Dodge, K. A., \& Coie, J. D. (1987). Social-information-processing factors in reactive and proactive aggression in children's peer groups. Journal of Personality and Social Psychology, 53, 1146-1158. 
Farmer, T.W., Estell, D.B., Bishop, J.L., O Neal, K.K, \& Cairns, B.D. (2003). Rejected Bullies or Popular Leaders? The Social Relatioins of Aggressive Subtypes of Rural African American Early Adolescents. Developmental Psychology, 39, 992-1004.

Fite, P.J., Raine, A., Stouthamer-Loeber, M., Loeber, R., \& Pardini, D.A. (2009). Reactive and Proactive Aggression in Adolescent Males. Criminal Justice and Behavior, 2,141-157.

Fite, P.J., Colder, C.R., \& Pelham, W.E. (2006). A factor analytic approach to distinguish pure and co-occuring dimensions of proactive and reactive aggression. Journal of Clinical Child and Adolescent Psychology, 365, 4, 578-582.

Killen, M., Mulvey, K. L. \& Hitti, A. (2013). Social Exclusion in Childhood: A Developmental Intergroup Perspective. Child Development, 84, 772-790. doi: $10.1111 /$ cdev.12012

Lease, A. M., Kennedy, C. A., \& Axelrod, J. L. (2002). Children's social constructions of popularity. Social Development, 11, 87-109.

Newcombe, A.F., Bukowski, W.M., \& Pattee, L.(1993). Children s peer relations: a metaanalytic review of popular, rejected, neglected, controversial, and average sociometric status. Psychological Bulletin, 1, 99-128.

Olweus, D. (2001). Peer Harassment: A Critical Analysis and Some Important Issues, in Peer Harassment in School, ed: Juvonen, J., Graham, S. Guilford Publications, New York, 320.

Peets, K., Hodges, E. V. E. \& Salmivalli, C. (2011). Actualization of Social Cognitions into Aggressive Behavior toward Disliked Targets. Social Development, 20, 233-250.

Rodkin, P. C., Farmer, T. W., Pearl, R., \& Van Acker, R. (2000). Heterogeneity of popular boys: Antisocial and prosocial configurations. Developmental Psychology, 36,14-24.

Rodkin, P., Farmer, T., Pearl, R. \& Van Acker, R. (2006). They re cool: Social status and peer group supports for aggressive boys and girls. Social Development, 15, 175-204.

Rose, A.J., Swenson, L.P., \& Waller, E.M. (2004). Overt and relational aggression and popularity: Developmental differences in concurrent and prospective relations. Developmental Psychology, 40, 378-387.

Rubin, K.H., Bukowski, W.M., \& Parker, J.G. (1998). Peer interactions, relationships, and groups. In W. Damon (series ed.) și N. Eisenberg (vol. Ed.), Handbook of child psychology, vol. 3, Social, emotional, and personality development, p. 619-700, NY: Wiley

Steinberg, L., Sharp, C., Stanford, M., \& Tharp, A.T.(2O13). New tricks for an old measure: The development of theBarratt Impulsiveness Scale-Brief (BIS-Brief). Psychological Assessment, 25, 216-226.

Stoltz, S., Cillessen, A. H.N., van den Berg, Y. H.M. \& Gommans, R. (2015). Popularity differentially predicts reactive and proactive aggression in early adolescence. Aggressive Behavior. doi: 10.1002/ab.21603

Toblin, R. L., Schwartz, D., Hopmeyer Gorman, A., \& Abou-Ezzeddine, T. (2005). Socialcognitive and behavioral attributes of aggressive victims of bullying. Journal of Applied Developmental Psychology, 26, 329-346.

Vitaro, F., Brendgen, M., \& Barker, E. (2006). Subtypes of aggressive behaviors: a developmental perspective. International Journal of Behavioral Development, 1, 12-19. 